\title{
Quantifying development to inform management of Mojave and Sonoran desert tortoise habitat in the American southwest
}

\author{
Sarah K. Carter ${ }^{1, *}$, Kenneth E. Nussear ${ }^{2}$, Todd C. Esque ${ }^{3}$, Ian I. F. Leinwand ${ }^{4,8}$, \\ Elroy Masters ${ }^{5}$, Richard D. Inman ${ }^{3,6}$, Natasha B. Carr ${ }^{1}$, Linda J. Allison ${ }^{7}$ \\ ${ }^{1}$ US Geological Survey, Fort Collins Science Center, Fort Collins, Colorado 80526, USA \\ ${ }^{2}$ Department of Geography, University of Nevada, Reno, Nevada 89557, USA \\ ${ }^{3}$ US Geological Survey, Western Ecological Research Center, Las Vegas Field Station, Henderson, Nevada 89074, USA \\ ${ }^{4}$ Cherokee Services Group, Inc., on contract to US Geological Survey, Fort Collins Science Center, Fort Collins, \\ Colorado 80526, USA \\ ${ }^{5}$ Bureau of Land Management, Arizona State Office, Phoenix, Arizona 85004, USA \\ ${ }^{6}$ School of Geographical Sciences and Urban Planning, Arizona State University, Tempe, Arizona 85287, USA \\ ${ }^{7}$ Desert Tortoise Recovery Office, US Fish and Wildlife Service, Reno, Nevada 89502, USA \\ ${ }^{8}$ Present address: Conservation Science Partners, Inc., Fort Collins, Colorado 80524, USA
}

\begin{abstract}
Two tortoise species native to the American southwest have experienced significant habitat loss from development and are vulnerable to ongoing threats associated with continued development. Mojave desert tortoises Gopherus agassizii are listed as threatened under the US Endangered Species Act, and Sonoran desert tortoises G. morafkai are protected in Arizona (USA) and Mexico. Substantial habitat for both species occurs on multiple-use public lands, where development associated with traditional and renewable energy production, recreation, and other activities is likely to continue. Our goal was to quantify development to inform and evaluate actions implemented to protect and manage desert tortoise habitat. We quantified a landscapelevel index of development across the Mojave and Sonoran desert tortoise ranges using models of potential habitat for each species (152 485 total observations). We used 13 years of Mojave desert tortoise monitoring data (4732 observations) to inform the levels and spatial scales at which tortoises may be affected by development. Most (66-70\%) desert tortoise habitat has some development within $1 \mathrm{~km}$. Development levels on desert tortoise habitat are lower inside versus outside areas protected by actions at national, state, and local levels, suggesting that protection efforts may be having the desired effects and providing a needed baseline for future effectiveness evaluations. Of the relatively undeveloped desert tortoise habitat, $43 \%\left(74030 \mathrm{~km}^{2}\right)$ occurs outside of existing protections. These lands are managed by multiple federal, state, and local entities and private landowners, and may provide opportunities for future land acquisition or protection, including as mitigation for energy development on public lands.
\end{abstract}

KEY WORDS: Public lands - Terrestrial development - Gopherus agassizii · Gopherus morafkai · Bureau of Land Management · Mitigation · Renewable energy

\section{INTRODUCTION}

Traditional and renewable energy development is a prominent fixture in deserts of the American southwest, with significant negative impacts on the conser-

${ }^{*}$ Corresponding author: skcarter@usgs.gov vation value of these lands (Allred et al. 2015, Parker et al. 2018). Utility-scale solar and wind energy projects in particular have increased substantially in recent years as part of efforts to meet renewable energy production targets (Lovich \& Ennen 2011, Parker et

() K. E. Nussear, I. I. F. Leinwand, and outside the USA, the US Government 2020. Open Access under Creative Commons by Attribution Licence. Use, distribution and reproduction are unrestricted. Authors and original publication must be credited.

Publisher: Inter-Research · www.int-res.com 
al. 2018). Most of these lands are public, and there is currently strong pressure to increase energy development on federally managed public lands in the USA (US Department of the Interior 2017, US Department of the Interior Secretarial Order 3366).

Development in the Mojave and Sonoran Deserts of the American southwest poses a significant threat to 2 desert tortoise species. Mojave desert tortoises Gopherus agassizii were listed as threatened under the US Endangered Species Act in 1990, and Sonoran desert tortoises G. morafkai are protected in both Arizona (USA) and Mexico (BLM 2008, Arizona Game and Fish Department 2012, US Fish and Wildlife Service 2015b). Both species have experienced significant habitat loss due to development, and continue to experience ongoing threats associated with development. Major threats to Mojave desert tortoises include many types of development (urbanization, roads and railroads, agriculture, energy and mineral development [particularly renewable energy], landfills, and utility corridors) along with off-highway vehicles, non-native invasive plants, fire, grazing, and military operations (Tracy et al. 2004, U.S. Fish and Wildlife Service 2011, Berry \& Murphy 2019). Major threats to Sonoran desert tortoises include wildfire, urban development, highways, utility corridors, and habitat fragmentation (Howland \& Rorabaugh 2002, Esque et al. 2003, Dutcher et al. 2020). Decreasing population trends of the Mojave desert tortoise in most locations (Esque et al. 2010, Allison \& McLuckie 2018) highlight the need for a more comprehensive evaluation of threats, including the increasing footprint of development, across the species' ranges to inform listing, recovery, and management decisions.

Development results in the direct loss of habitat for desert tortoises and other wildlife species as well as multiple indirect effects (Dale et al. 2005, Hansen et al. 2005, Leu et al. 2008). Housing development and associated infrastructure remove and alter soil and vegetation, increase noise and light (Barber et al. 2011, Kight \& Swaddle 2011), subsidize predators (McKinney 2002), alter nutrient and disturbance regimes, and expand diffuse human activities into surrounding natural areas (Leinwand et al. 2010). Roads fragment habitat (Ibisch et al. 2016), lead to direct wildlife mortality (von Seckendorff Hoff \& Marlow 2002, Boarman \& Sazaki 2006, Colino-Rabanal \& Lizana 2007), are a vector for the spread of nonnative invasive plants (Davies \& Sheley 2007, GavierPizarro et al. 2010), increase the presence of subsidized predators (Boarman et al. 2006, Esque et al. 2010), and provide access to previously remote areas. Energy development (e.g. oil and gas fields, geo- thermal facilities, solar arrays, wind turbines) increases noise, traffic, utility corridors, and roads, which further fragment or degrade remaining habitat (Kuvlesky et al. 2007, Jones et al. 2015).

Much habitat for both species of desert tortoise occurs on federally managed public lands, and most of these public lands are managed for diverse resource uses and values, which may include development. For example, the Bureau of Land Management (BLM) is required to manage its lands explicitly for multiple uses (Federal Land Policy and Management Act of 1976, 43 USC §1701) that often include livestock grazing, fish and wildlife habitat, outdoor recreation, timber harvest, mining, and oil, gas, wind, and solar energy production. The BLM is also responsible for maintaining or restoring habitats for federally listed species and special status species (Fundamentals of Rangeland Health, 43 CFR §4180.2). The Department of Defense also manages a suite of highly diverse federal lands that provide important habitat for many rare species, including desert tortoises, for multiple uses, including maintaining military readiness (Stein et al. 2008, Aycrigg et al. 2015).

Providing up to date data on the location, amount, and condition of habitat for priority species, such as desert tortoises, and on potential activities that may affect those resources, such as development, is key to resolving conflicts between diverse resource objectives on multiple-use public lands. Our goal was to quantify development across desert tortoise habitat to inform future conservation and management actions on public lands, particularly those managed by the BLM.

Our first objective was to evaluate threats from existing development to habitat for both species of desert tortoise using a consistent index of terrestrial development. Differences in methods used to quantify threats across the range of both desert tortoise species have until now precluded such an assessment. Comprehensive quantitative information on threats across a species' range is needed to inform listing, recovery, and management decisions (AverillMurray et al. 2012). Federal agencies also must analyze the cumulative effects of proposed development projects on public lands (National Environmental Policy Act, 40 CFR $\S \S 1500-1508)$, which requires consideration of other development actions that have occurred in the surrounding area over time. Quantifying existing development consistently across large areas can facilitate such landscape-level analyses at scales relevant to the species that may be impacted by the proposed action.

Our second objective was to evaluate threat levels in areas of desert tortoise habitat subject to protec- 
tions provided at 3 levels - nationally (congress or the president acting at a landscape level), by a federal management agency acting at the state level (the BLM Arizona State Office), and by a federal agency acting at a local level (the BLM Lake Havasu Field Office, through an individual BLM land use plan in Arizona). Examining differences in development levels inside and outside of these 3 protective designations provides insight into the types of federal actions that may be most effective in protecting desert tortoise habitat as well as a needed baseline for future effectiveness evaluations.

Our third objective was to identify areas of desert tortoise habitat that are still largely undeveloped and may warrant future conservation or mitigation action. Energy development, including construction of utility-scale solar energy facilities, is occurring on both federal and private lands in the region, and mitigation actions can be an important tool for accommodating development on multiple-use public lands without jeopardizing wildlife populations.

\section{MATERIALS AND METHODS}

\subsection{Study area}

Our study area includes the majority of the Mojave and Sonoran Deserts within the southwestern USA. The Mojave Desert covers $127689 \mathrm{~km}^{2}$, while the Sonoran Desert spans $89848 \mathrm{~km}^{2}$ in the USA (MacMahon \& Wagner 1985, US Environmental Protection Agency 1996). Where it occurs in southern California, the Sonoran Desert is more recently referred to as the Colorado Desert (US Environmental Protection Agency 1996, Keeler-Wolf et al. 2007). The region is characterized by many north-south running mountain ranges surrounded by low desert basins that are either closed or drained by tributaries of the Colorado River. These deserts have extremely hot summer temperatures frequently exceeding $40^{\circ} \mathrm{C}$. The Mojave Desert has slightly cooler winter temperatures than the Sonoran Desert, occasionally dropping below $0^{\circ} \mathrm{C}$. The entire region generally receives less than $250 \mathrm{~mm}$ of precipitation per year. Both deserts are sparsely vegetated with large components of desert shrubs and grasses and annual plant species. The Sonoran Desert supports columnar cacti and many smaller succulent plants due to its warmer winters, while the Mojave Desert has fewer succulent species but adds the Joshua tree (Turner 1994, Turner \& Brown 1994, Barbour et al. 2007).

In general, Mojave desert tortoises are those that occur west and north of the Colorado River in the
Mojave Desert, while Sonoran desert tortoises occur east and south of the Colorado River and south into Mexico (Murphy et al. 2011, Nussear \& Tuberville 2014). A population of tortoises of Mojave Desert genetic origin have also been identified east and south of the Colorado River, in the ecotone between both deserts near Kingman, Arizona (McLuckie et al. 1999, Edwards et al. 2015, Dolby et al. 2019). However, at the time federal protections were conferred, they were applied to the 'Mojave population' of the desert tortoise, which was defined geographically. Mojave desert tortoises east of the Colorado River do not have federal protection under the Endangered Species Act (US Fish and Wildlife Service 1990).

\subsection{Mapping potential habitat for desert tortoises}

We leveraged a previously developed index of potential habitat for desert tortoises (Inman et al. 2014, Edwards et al. 2015) that was derived from species distribution modeling, a quantitative modeling approach that relates locations of species observations to environmental covariates hypothesized to influence the suitability of habitat for a species (Franklin 2010). Observations of desert tortoises were compiled from multiple state and federal wildlife agency monitoring programs including the Nevada Department of Wildlife, California Department of Fish and Game, Arizona Department of Game and Fish, Utah Division of Wildlife Resources, and the US Fish and Wildlife Service. Additional observation records were compiled from published literature and internal US Geological Survey research collection databases for ongoing research projects in California and Nevada (Esque et al. 2010, Drake et al. 2015) for a total of 132877 and 19608 observations for Mojave and Sonoran desert tortoises, respectively, which were reduced to 7209 and 1513 occupied $1 \mathrm{~km}$ cells used to develop each model. We considered environmental covariates previously found to be important to desert tortoise habitat (e.g. winter precipitation, surface roughness, Nussear et al. 2009), as well as new covariates that spanned physiographic, climatic, and surface characteristics of extant desert tortoise habitat (e.g. surface texture; Inman et al. 2014, Edwards et al. 2015, Nowicki et al. 2019). We defined potential habitat (hereafter, habitat) for each species as the modeled area above a suitability threshold of 0.54 and 0.33 for Mojave and Sonoran desert tortoises, respectively, using the $95^{\text {th }}$ percentile of inclusion for modeling points (Liu et al. 2005). The final habitat map was a compilation of separate models created for each species. 


\subsection{Constructing a landscape-level development index relevant to desert tortoises}

We used a terrestrial development index (hereafter, development index) to evaluate landscape-level effects of development (Carr et al. 2017). This index is derived from the surface disturbance footprint of terrestrial development (hereafter, development) for the western USA. We mapped the development footprint by combining spatial data for urban development, cultivated agriculture, energy development (e.g. oil and gas well pads, solar energy facilities), surface mines and quarries, pipelines and transmission lines, and transportation (e.g. roads and railroads). We briefly summarize methods here; see Carr et al. $(2016,2017)$ for detailed methods and datasets. Linear features and points were buffered and combined with polygonal data, rasterized at $15 \mathrm{~m}$, aggregated to $30 \mathrm{~m}$, and then combined with the $30 \mathrm{~m}$ inputs for urban development and cultivated croplands. This footprint area was represented as a proportion of the pixel and summed using a raster calculator. To reduce processing time, the $30 \mathrm{~m}$ footprint was then aggregated to $90 \mathrm{~m}$. Finally, we applied a moving window analysis to the footprint, which calculates the percent of the land surface occupied by the disturbance footprint within a specified radius of each $90 \mathrm{~m}$ pixel.

The development index is flexible, allowing for consideration of different analysis scales (Carr et al. 2017). We considered desert tortoise biology and tested the relationship between the development index and Mojave desert tortoise observations to determine the most appropriate radius for the moving window analysis. Desert tortoises are affected by roads to a distance of at least $1 \mathrm{~km}$ (von Seckendorff Hoff \& Marlow 2002, Boarman \& Sazaki 2006), and are known to occasionally move long distances (Duda et al. 1999, Freilich et al. 2000, Berish \& Medica 2014), potentially exposing them to risks from development occurring much farther away. Thus we considered and tested analysis extents of $1 \mathrm{~km}$ and greater for the development index.

We also analyzed long-term monitoring data for the Mojave desert tortoise (described in US Fish and Wildlife Service 2016) and radii of 1, 2.5, 5, 10, and $15 \mathrm{~km}$ to identify the moving window radius for the development index that would explain the most variability in the number of desert tortoises observed. Long-term monitoring data were not available for the Sonoran desert tortoise. Because both species have lower densities within $1 \mathrm{~km}$ of roads, have similar daily movement patterns, and are capable of long- distance movement on occasion, we applied results from the Mojave desert tortoise rangewide for both species as an initial approximation of sensitivity to levels and spatial scales of development for both tortoise species.

The Mojave desert tortoise monitoring data were (1) spatially aggregated with different areas sampled among years, and (2) $12 \mathrm{~km}$ in length (transects walked in a square with sides $3 \mathrm{~km}$ in length). To reduce these biases, we segmented and resampled transects. Collectively, we examined 13 years of tortoise observations from 2001 to 2014 (no sampling was conducted in 2006) across 31 strata ( $\mathrm{n}=4732$ observations total) that were repeatedly sampled within 4 of the 5 recovery units for Mojave desert tortoises (Colorado Desert, Western Mojave, Northeastern Mojave, and Eastern Mojave; US Fish and Wildlife Service 2011, 2015a, Allison \& McLuckie 2018). We sampled the monitoring data to reduce spatial and temporal bias by first segmenting transects using a $250 \mathrm{~m}$ grid. We then created 100 monitoring datasets by randomly sampling all segments from up to 5 transects (uniquely identified among years) that were surveyed within a 10 by $10 \mathrm{~km}$ grid over the entire study area. This resulted in 100 datasets comprised of 67320 to 71490 segments each, with each segment averaging $169 \mathrm{~m}$ in length. We modeled the relationship between the development index for all radii specified above and numbers of live and dead tortoises while controlling for segment length (see Table 2) using zero-inflated negative binomial regressions (package 'pscl' v 1.4.9, in $\mathrm{R} 3.3 .2$, $\mathrm{R}$ Core Team 2016). We included segment length and habitat suitability for each segment as covariates in the analyses.

\subsection{Determining levels of development relevant to desert tortoises}

The same long-term monitoring data for Mojave desert tortoises (US Fish and Wildlife Service 2016) and analyses described in Section 2.3 also allowed us to model the relationship between numbers of observations of live and dead tortoises and the associated level of the development index for each observation site. As explained above, we applied these relationships to Sonoran Desert tortoise habitat as well, as an initial approximation for that species. We refer to areas with no development within $1 \mathrm{~km}$ as undeveloped areas or areas least impacted by development. 


\subsection{Applying the development index to inform management of desert tortoise habitat}

\subsubsection{Evaluating threats from existing development to habitat for desert tortoises}

We mapped and quantified the frequency distribution of the development index across habitat for both tortoise species and for areas of habitat managed by different entities. We used the Protected Areas Database of the US (US Geological Survey 2016) to identify jurisdiction for all lands. We combined some entities that manage relatively small areas of habitat into larger categories (Table 1): 'Department of Defense' includes lands managed by the Department of Defense and the US Army Corps of Engineers; 'Other federal agencies' includes lands managed by the US Department of Agriculture-Agricultural Research Stations, US Bureau of Reclamation, and US Department of Energy; 'Native American tribes' includes lands managed by multiple sovereign tribes; 'State and local lands' include multiple categories of state, county, local, and regional jurisdiction; 'Private lands,' include lands listed as privately owned, as well as a few areas of lands managed by non-governmental organizations and of undetermined ownership.

\subsubsection{Evaluating threat levels on desert tortoise habitat protected by actions at national, state, and local levels}

We evaluated threat levels on desert tortoise habitat occurring on lands protected directly by national action (designation by congress or the president), by a federal agency acting at the state level (the BLM Arizona State Office), and by a federal agency acting at a local level (the BLM Lake Havasu Field Office in Arizona). The strongest and most durable level of protection for public lands is generally provided by national direct action through executive and congressional designations (e.g. wilderness areas, national parks, national monuments, national conservation areas). These lands are designated as Gap Analysis Project (GAP; Gergely et al. 2019) status 1 and 2 protected areas (US Geological Survey 2016). Thus, we first compared development levels in Mojave and Sonoran desert tortoise habitat occurring on federal lands inside and outside of GAP status 1 and 2 protected areas (combined, US Geological Survey 2016).

Desert tortoise habitat occurring on federal lands can also be protected by federal agencies acting at state levels based on their agency authorities, and we evaluated such actions in Arizona. The BLM Arizona State Office has designated the Sonoran Desert tortoise as a BLM Sensitive Species in Arizona and made it a priority for management on all BLM lands in the state. Desert tortoise habitat in Arizona (largely Sonoran desert tortoise, but including the small area in which tortoises are of Mojave Desert origin; McLuckie et al. 1999, Edwards et al. 2015) is managed based on 3 habitat categories with the following goals; Category 1: maintain stable, viable populations, protect existing tortoise habitat values, and increase populations where possible; Category 2: maintain stable, viable populations and halt further declines in tortoise habitat values; and Category 3: limit tortoise habitat and population declines to the extent possible by mitigating impacts (Spang et al. 1988). BLM implements different conservation actions to meet the category goals. For example, development may be restricted to meet Category 1 habitat objectives. Protections for desert tortoise habitat in each category are implemented through the BLM resource management planning process. The plans guide all permitting and authorized use decisions on lands managed by the agency. We compared development levels for desert tortoise habitat occurring on public lands managed by BLM Arizona within each category versus outside of all 3 categories. Spatial data for Category 1, 2, and 3 desert tortoise habitats were acquired from the BLM Arizona State Office.

Specific land use designations adopted through individual BLM resource management plans (which are generally developed at spatial extents of tens to hundreds of thou- 
sands of square kilometers) can also provide protection for desert tortoise habitat. Thus, our most local comparison evaluated development levels inside and outside of areas protected by planning within a single field office. Specifically, we compared development levels for desert tortoise habitat on BLM lands in Arizona within and outside of 2 groups of land use designations in the Lake Havasu Resource Management Plan (BLM 2007): areas protected for wildlife and areas with minerals management restrictions. Areas protected for wildlife include wildlife habitat areas and wildlife corridors, which both restrict facilities and communication towers, if practical, and require that mitigation be possible that maintains wildlife as the primary use for the lands (BLM 2007). Areas with minerals management restrictions include: (1) no surface occupancy for leasable minerals (i.e. facilities are not permitted), (2) areas withdrawn from locatable minerals (i.e. no new mining operations are permitted), and (3) areas excluded from saleable minerals (i.e. no new sand and gravel operations are permitted, BLM 2007). GIS data for lands under these protective designations were provided by the BLM Arizona State Office.

\subsubsection{Identifying desert tortoise habitat that may warrant future protection}

We mapped, quantified, and identified the agencies and organizations that manage areas of desert tortoise habitat that may warrant future protection. We defined these areas as being currently undeveloped $(0 \%$ development within $1 \mathrm{~km})$ or having low development (1-4\% development within $1 \mathrm{~km})$, and being vulnerable to future development because they are (1) not currently permanently protected (i.e. GAP status 1 or 2 protected areas) and (2) not currently designated as Category 1, 2, or 3 desert tortoise habitat by the BLM Arizona State Office.

\section{RESULTS}

\subsection{Mapping habitat for desert tortoises}

We identified 90269 and $78228 \mathrm{~km}^{2}$ of habitat for Mojave and Sonoran desert tortoises, respectively, by leveraging previously compiled maps of habitat for each species (Edwards et al. 2015, Inman et al. 2019) and expanding the boundaries of the most widely used distribution model for desert tortoises (Nussear et al. 2009) to include all known habitat in Arizona.

\subsection{Constructing a landscape-level development index relevant to desert tortoises}

We found that a radius of $1 \mathrm{~km}$ most frequently explained the greatest variability in the number of Mojave desert tortoise observations out of the suite of candidate models containing the development index summarized at radii of $1,2.5,5,10$, and $15 \mathrm{~km}$ for 100 geographically stratified random draws of the segment data (69 of 100 datasets, Table 2). We therefore used a $1 \mathrm{~km}$ radius for quantifying the development index for all subsequent analyses.

\subsection{Determining levels of development relevant to desert tortoises}

We found that encounter rates for both live and dead Mojave desert tortoises combined decreased significantly with development levels (an average of $4 \%$ decrease for every $1 \%$ increase in the development index), while controlling for variation due to habitat suitability and the transect segment length surveyed (Table 2). There were few detections of either live or dead animals above a development index value of $10 \%$ (meaning that $10 \%$ of the area within $1 \mathrm{~km}$ of that location has been altered by development, Fig. 1). While there was a mix of low encounter rates across all levels of the development index (Fig. 1), the maximum encounter rates were negatively associated with development level, becoming essentially zero for live animals above an index value of $10 \%$ (Fig. 2).

\subsection{Applying the development index to inform management of desert tortoise habitat}

\subsubsection{Evaluating threats from existing development to habitat for desert tortoises}

Most habitat for both tortoise species (66 and 70\% for Mojave and Sonoran desert tortoises, respectively) had some development within $1 \mathrm{~km}$ (Fig. 3). Five percent and $12 \%$ of habitat for Mojave and Sonoran tortoises, respectively, had a development index of greater than $10 \%$. As expected, levels of development in habitat for both species were highest near cities (Tucson and Phoenix, Arizona; Las Vegas, Nevada; several smaller municipalities and outlying areas along the Colorado River; and smaller municipalities near Los Angeles, California) because of their large urban footprint (Fig. 3). The total footprint 
Table 2. Model covariates and percentage of times each was the best model in 100 randomly drawn datasets. Model 8, which included terms for transect segment length, desert tortoise habitat suitability, and the terrestrial development index (TDI) using a $1 \mathrm{~km}$ radius was the best model in the majority (69\%) of the runs

\begin{tabular}{|c|c|c|c|c|c|c|c|c|c|}
\hline Model & $\begin{array}{l}\text { Transect } \\
\text { segment } \\
\text { length }\end{array}$ & $\begin{array}{c}\text { Desert } \\
\text { tortoise habitat } \\
\text { suitability }\end{array}$ & $\begin{array}{c}\text { TDI } \\
1 \mathrm{~km}\end{array}$ & $\begin{array}{c}\text { TDI } \\
2.5 \mathrm{~km}\end{array}$ & $\begin{array}{c}\text { TDI } \\
5 \mathrm{~km}\end{array}$ & $\begin{array}{c}\text { TDI } \\
10 \mathrm{~km}\end{array}$ & $\begin{array}{c}\text { TDI } \\
15 \mathrm{~km}\end{array}$ & $\begin{array}{c}\text { TDI } \\
20 \mathrm{~km}\end{array}$ & $\begin{array}{c}\% \text { of } \\
100 \text { datasets }\end{array}$ \\
\hline 1 & $X$ & & & & & & & & 0 \\
\hline 2 & $X$ & & $\mathrm{X}$ & & & & & & 0 \\
\hline 3 & $X$ & & & $\mathrm{X}$ & & & & & 0 \\
\hline 4 & $X$ & & & & $\mathrm{X}$ & & & & 0 \\
\hline 5 & $X$ & & & & & $X$ & & & 0 \\
\hline 6 & $X$ & & & & & & $X$ & & 0 \\
\hline 7 & $X$ & & & & & & & $X$ & 0 \\
\hline 8 & $\mathrm{X}$ & $X$ & $\mathrm{X}$ & & & & & & 69 \\
\hline 9 & $\mathrm{X}$ & $\mathrm{X}$ & & $\mathrm{X}$ & & & & & 1 \\
\hline 10 & $X$ & $X$ & & & $\mathrm{X}$ & & & & 3 \\
\hline 11 & $X$ & $\mathrm{X}$ & & & & $\mathrm{X}$ & & & 4 \\
\hline 12 & $\mathrm{X}$ & $\mathrm{X}$ & & & & & $\mathrm{X}$ & & 4 \\
\hline 13 & $X$ & $\mathrm{X}$ & & & & & & $X$ & 19 \\
\hline
\end{tabular}

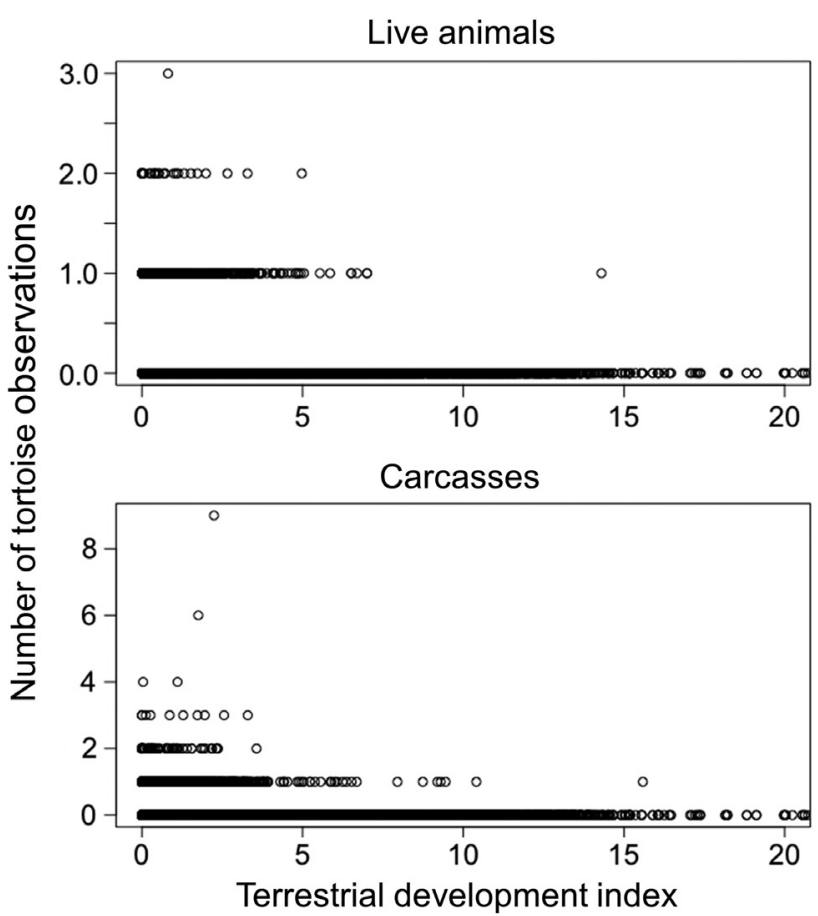

Fig. 1. Numbers of live desert tortoises and carcasses encountered on transect segments versus the terrestrial development index calculated at $1 \mathrm{~km}$. A development index value of 5 indicates that $5 \%$ of the area within $1 \mathrm{~km}$ of that location has been altered by development

of development within habitat for Mojave desert tortoises $\left(185 \mathrm{~km}^{2}\right)$ was substantially less than that for Sonoran Desert tortoises $\left(496 \mathrm{~km}^{2}\right)$.

Desert tortoise habitat is managed by multiple partners (Fig. 4). The BLM manages the largest area of habitat for both Mojave and Sonoran desert tor-

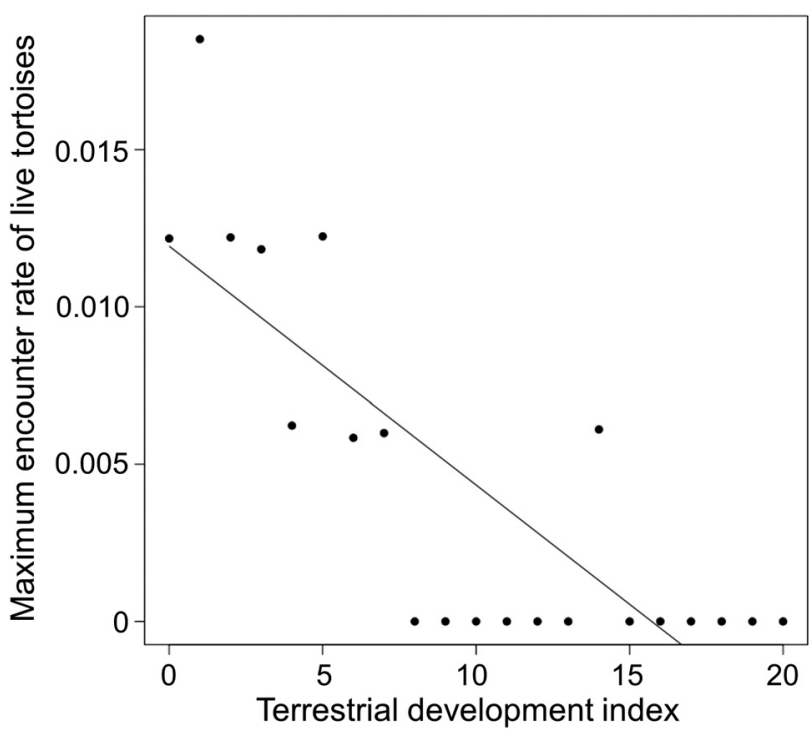

Fig. 2. Maximum encounter rates (tortoises $\mathrm{m}^{-1}$ ) for live desert tortoises versus the terrestrial development index calculated at a radius of $1 \mathrm{~km}$ and binned at $1 \%$ intervals. Maximum encounter rates were significantly correlated with the terrestrial development index $\left(p<0.001, r^{2}=0.65\right)$. A development index value of 5 indicates that $5 \%$ of the area within $1 \mathrm{~km}$ of that location has been altered by development

toises (54.0 and 30.6\%, respectively, Table 1), with $36 \%$ of those lands currently having no development within $1 \mathrm{~km}$. The US Fish and Wildlife Service, National Park Service, US Forest Service, and the Department of Defense collectively manage another $26 \%$ of desert tortoise habitat; $41-60 \%$ of the lands managed by these agencies have no development within $1 \mathrm{~km}$. Together, state and local lands and pri- 


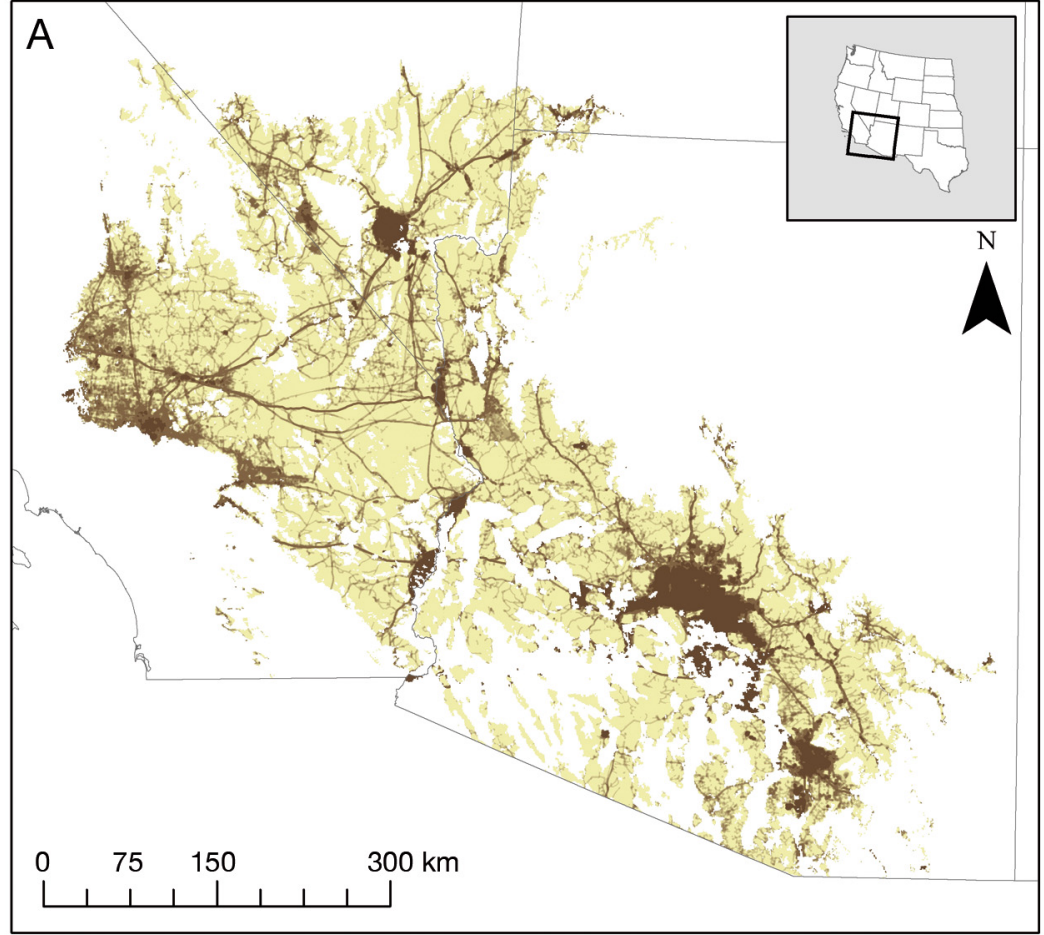

Terrestrial development index

Percent development within $1 \mathrm{~km}$ radius

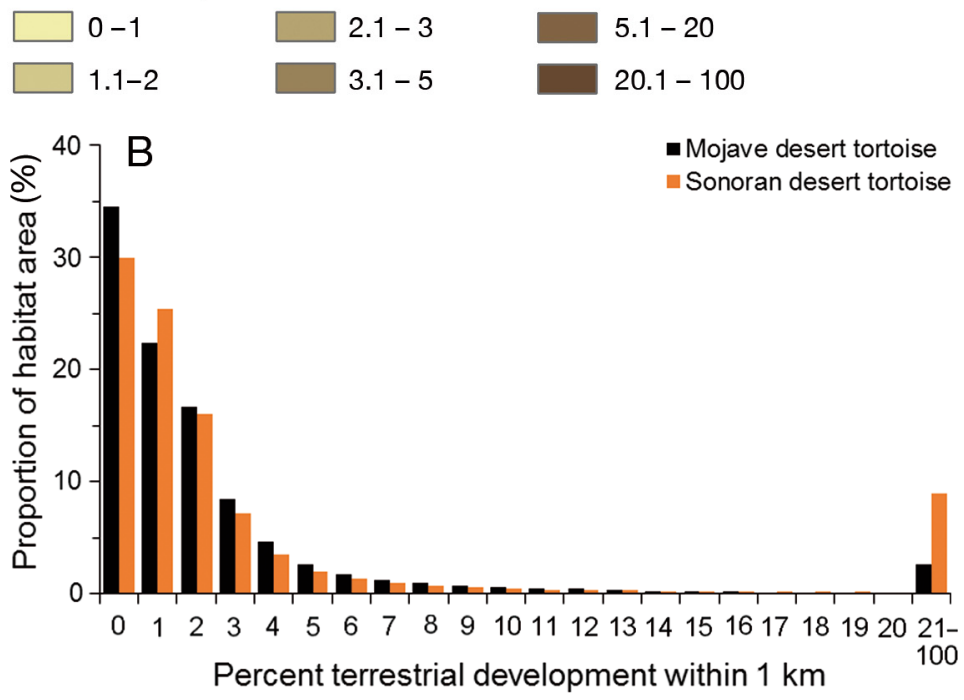

Fig. 3. (A) Terrestrial development levels (shown in shades of brown) for Mojave and Sonoran desert tortoise habitat. A value of $1 \%$ indicates that $1 \%$ of the surface area within $1 \mathrm{~km}$ of that $90 \mathrm{~m}$ pixel is altered by development from urban areas, energy development, transportation infrastructure, or cultivated agriculture. (B) Frequency distribution of development levels for Mojave and Sonoran desert tortoise habitat

vate lands also encompass a substantial portion of desert tortoise habitat (24\%), and have higher development levels $(19 \%$ of state and local lands, and $7 \%$ of private lands have no development within $1 \mathrm{~km}$, Fig. 5).
3.4.2. Evaluating threat levels on desert tortoise habitat protected

by actions at national, state, and local levels

Overall, 48\% (35979 $\left.\mathrm{km}^{2}\right)$ and $28 \%$ $\left(11797 \mathrm{~km}^{2}\right)$ of habitat for Mojave and Sonoran desert tortoises, respectively, on federal lands is permanently protected (GAP status 1 or 2 protected area) by executive or congressional designations (Fig. 6). Development levels on federally managed desert tortoise habitat were substantially lower inside versus outside of these permanently protected areas (Fig. 6B,C). For the Mojave desert tortoise, $47 \%$ of habitat on federal lands inside versus $32 \%$ outside of GAP status 1 and 2 protected areas had no development within $1 \mathrm{~km}$. For the Sonoran desert tortoise, $59 \%$ of habitat on federal lands inside versus $34 \%$ outside of GAP status 1 and 2 protected areas had no development within $1 \mathrm{~km}$.

In Arizona, 8, 33, and $31 \%$ of desert tortoise habitat managed by BLM has been designated as Category 1, 2, and 3 habitat, respectively. In many cases, this protection enacted at the state level is in addition to congressionally designated protection (Fig. 7). On BLM-administered lands in Arizona, $35-45 \%$ of Category 1,2 , and 3 designated habitat had no development within $1 \mathrm{~km}$, compared to $28 \%$ of uncategorized habitat (Fig. 7).

In the area managed by the Lake Havasu Field Office, $70 \%$ of Sonoran Desert tortoise habitat on BLM lands occurs in areas protected for wildlife, and $22 \%$ occurs in areas with minerals management restrictions implemented at the local level through the Lake Havasu Field Office Resource Management Plan (Fig. 8). In many cases, these local designations represent an additional protection mechanism on top of that provided at the state or national level. Of desert tortoise habitat on BLM lands with minerals management or wildlife restrictions, 39\% had no development within $1 \mathrm{~km}$, compared to $22 \%$ on lands without these restrictions (Fig. 8). 

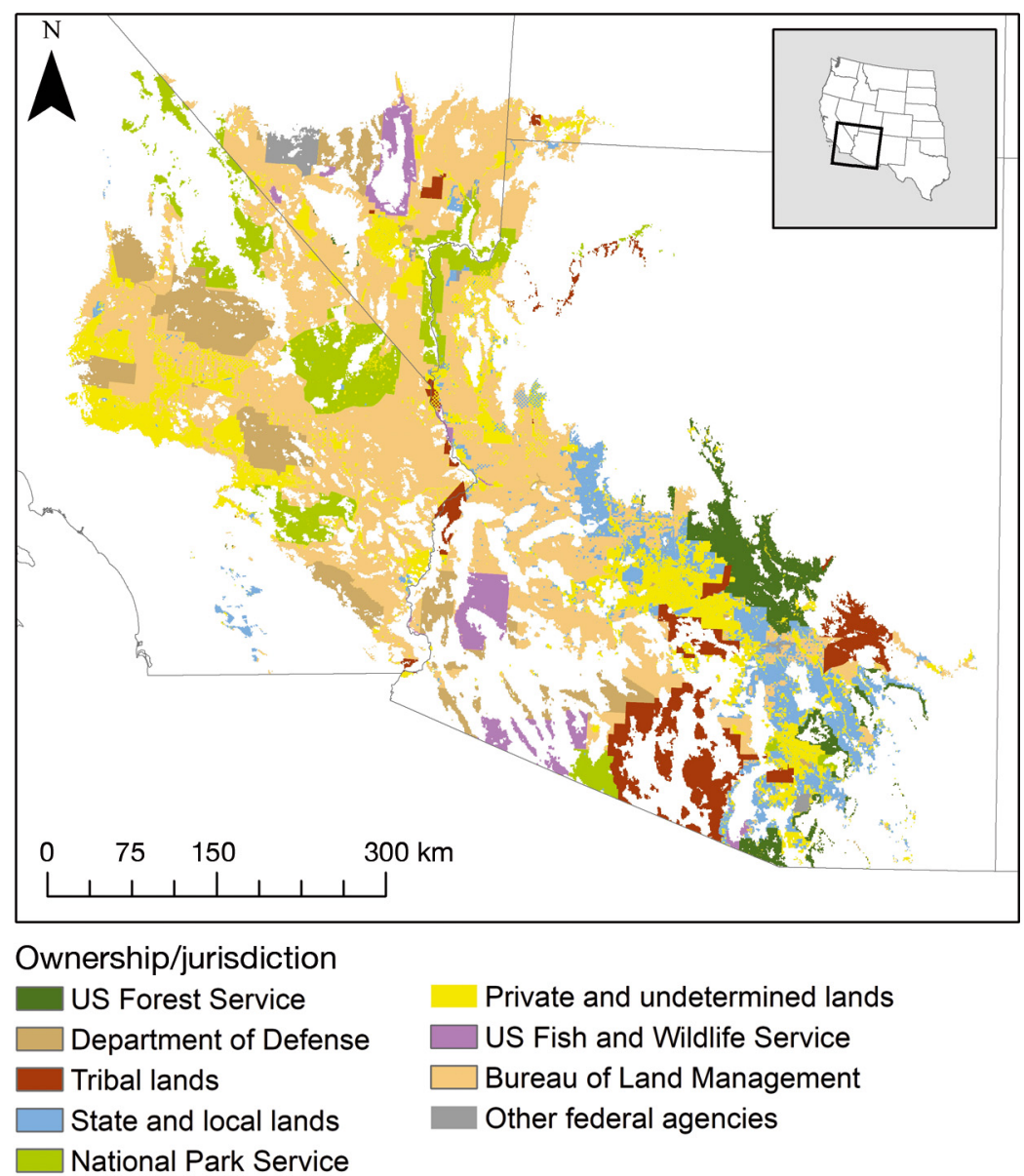

Fig. 4. Jurisdictions, landowners, and land managers for Mojave and Sonoran desert tortoise habitat

\subsubsection{Identifying desert tortoise habitat that may warrant future protection}

Increasing levels of development corresponded with decreasing desert tortoise observations. However, there was no clear breakpoint below 10\% that separated areas of high versus low numbers of tortoise observations. As a result, we present information on desert tortoise habitat outside of existing strongly protected areas (GAP status 1 and 2 protected areas and BLM Arizona designated desert tortoise habitat) that had development levels from 0 to $4 \%$, a level that encompasses about $85 \%$ of all desert tortoise habitat. Of Mojave and Sonoran desert tortoise habitat, $42036 \mathrm{~km}^{2}$ (46\%) and $31994 \mathrm{~km}^{2}$ (41\%), respectively, had $4 \%$ or less development within $1 \mathrm{~km}$ and may be vulnerable to future development because they occur outside of both GAP status 1 and 2 protected areas and BLM designated desert tortoise habitat in Arizona (Fig. 9). Of these lands, 39\% are managed by BLM, $16 \%$ by the Department of Defense, $8 \%$ by the US Forest Service, $2 \%$ by the National Park Service, and $2 \%$ by other federal agencies; $12 \%$ are tribal lands, $12 \%$ are 'Private lands', and 9\% are 'State and local lands'.

\section{DISCUSSION}

Key principles of a landscape-level approach to managing public lands include explicitly acknowledging and evaluating the resource tradeoffs required to meet diverse objectives in multifunctional landscapes (Sayer et al. 2013, Freeman et al. 2015). Understanding where and to what extent development on public lands may impact priority habitat for rare species allows managers to fully consider these tradeoffs when making planning and management decisions about conflicting resource objectives. We found that $66-70 \%$ of desert tortoise habitat has some development within $1 \mathrm{~km}$, and that relatively high development levels occur in some areas protected for Mojave desert tortoises, which are listed under the US Endangered Species Act. Areas of habitat inside protective designations enacted at national, state, and local levels did, however, consistently have lower development than habitat outside of these areas. Further, $74030 \mathrm{~km}^{2}$ of desert tortoise habitat occurring outside of areas protected by national and state-level designations have no or low development, providing significant opportunities for future conservation action on lands of various jurisdictions, including private lands.

\subsection{Evaluating threats from existing development to desert tortoise habitat}

A quantitative assessment of development threats to desert tortoise habitat was not previously possible because of differences in methodologies used to assess threats from development in different areas of the species' ranges (e.g. Strittholt et al. 2012, Comer et al. 2013). Our results, quantified consistently for all land ownerships across the range of both species, can 

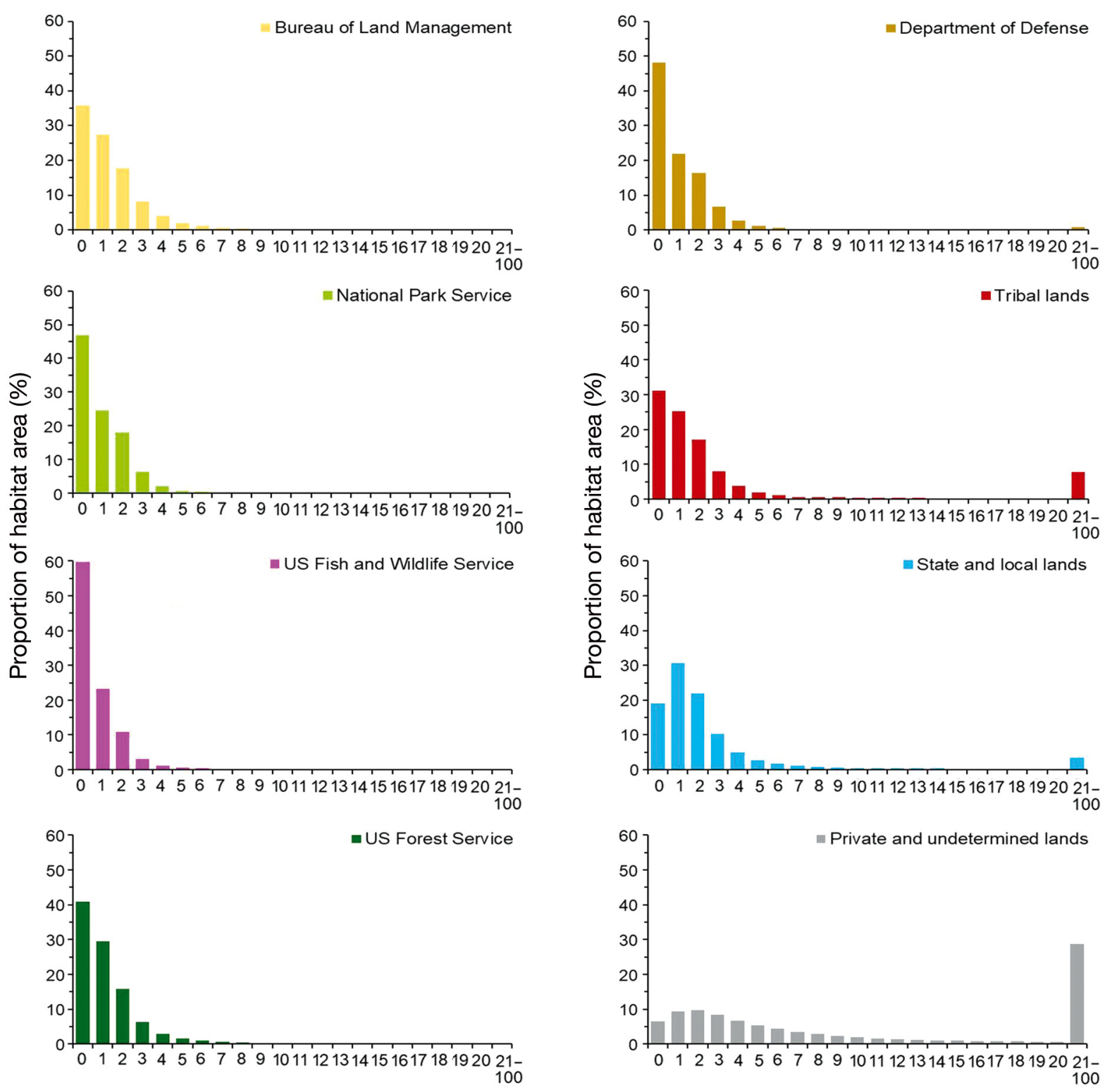

Percent terrestrial development within $1 \mathrm{~km}$

Fig. 5. Frequency distribution of development levels for major landowners/jurisdictions of desert tortoise habitat (both species combined)

help target conservation actions toward locations where they may be most effective and inform partner roles in achieving an 'all lands' approach to desert tortoise habitat management.

Nearly half of the desert tortoise habitat managed by the National Park Service and by the Department of Defense, federal entities with quite different missions, has no development within $1 \mathrm{~km}$. The National Park Service is dedicated to conserving natural and cultural resources unimpaired for future generations. Although the primary mission of installations managed by the Department of Defense is to deter war and protect the security of the country, the department also manages military lands to support other national priorities. Under the Sikes Act (16 USC $\S 670)$, military installations establish conservation plans and activities through Integrated Natural Resource Management Plans, and these have been the primary basis for planning and coordinating with state and federal wildlife agencies. The recently implemented Recovery and Sustainment Partnership Initiative between the Departments of Defense and the Interior seeks to develop and promote effective species conservation and recovery and to provide in- 


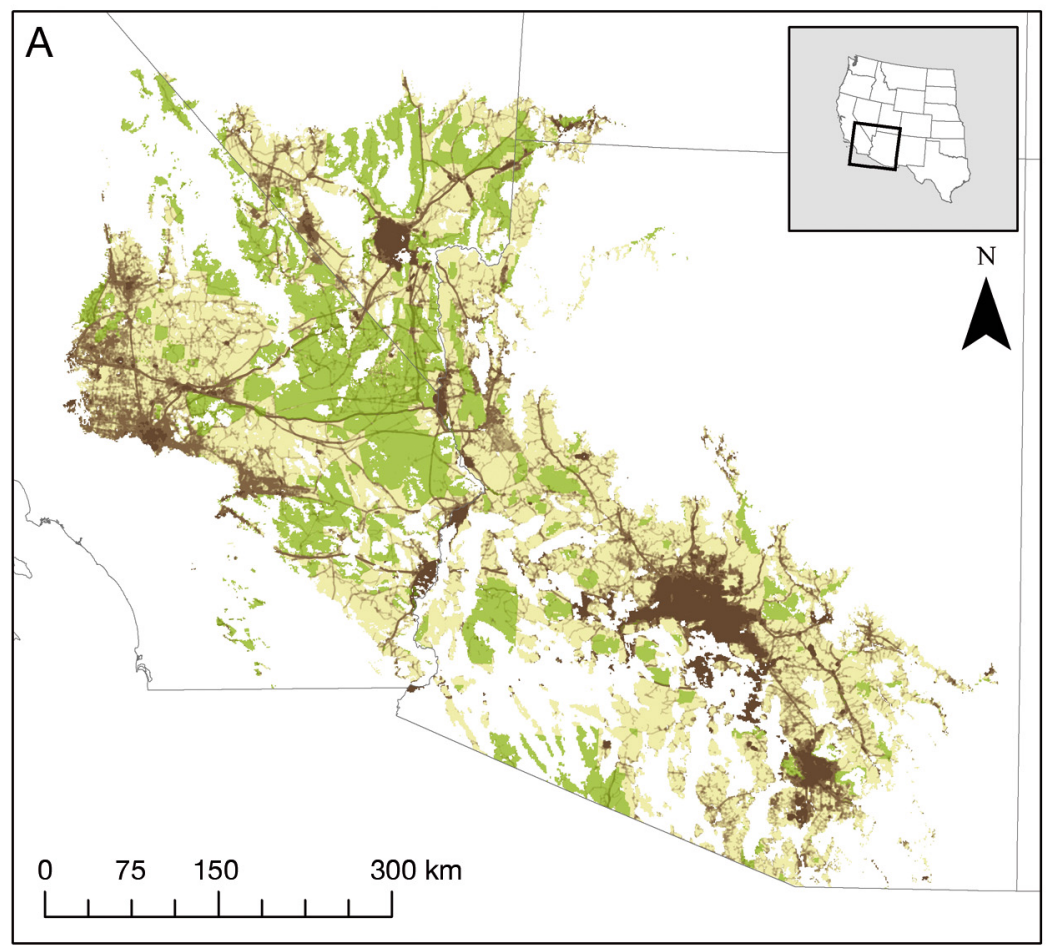

Protected desert tortoise habitat

GAP status 1 and 2 protected areas

Terrestrial development index

Percent development within $1 \mathrm{~km}$ radius
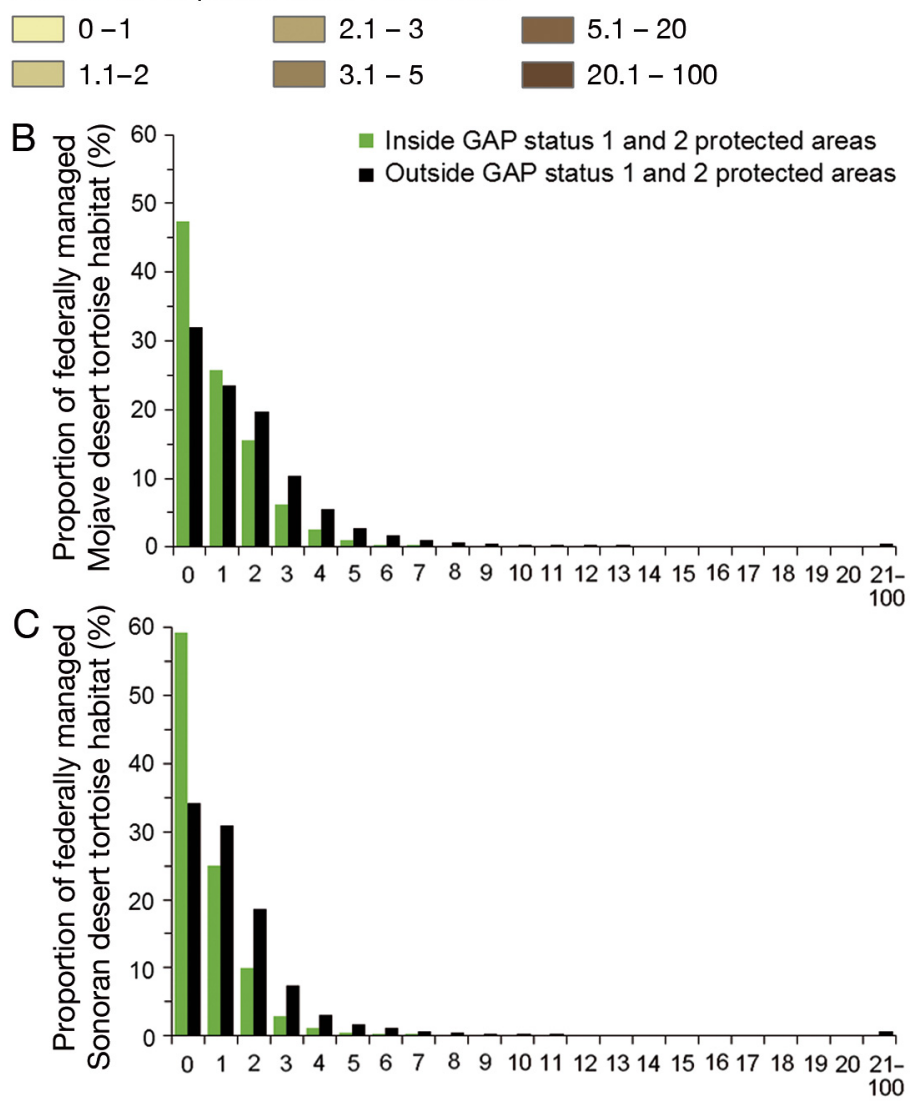

Percent terrestrial development within $1 \mathrm{~km}$ creased flexibility for military mission activities. The development patterns uncovered in the present study can help inform these efforts to conserve desert tortoise habitat on non-military lands while facilitating military operations.

The US Fish and Wildlife Service is implementing recovery actions for the Mojave desert tortoise rangewide using a decision management system to prioritize conservation actions in specific areas (Averill-Murray et al. 2012, 2013, Darst et al. 2013). Those actions currently target Areas of Critical Environmental Concern (ACECs) that the BLM has designated for Mojave desert tortoises. However, there is also interest in implementing conservation actions on lands surrounding these ACECs to increase their connectivity and resilience (Averill-Murray et al. 2013). Our results can help such efforts focus on-theground habitat management and restoration actions in areas where development is lowest, potentially providing the greatest overall benefits for tortoises.

Our findings can also be used to identify different roles and actions for partners. For example, land managers responsible for large areas of habitat near roads may provide tortoise-fencing or culverts to reduce the threat from that development to otherwise highquality habitat areas. Agencies, such as the BLM, that manage many unpaved roads may consider closing some roads seasonally or permanently to reduce the effects of that development on tortoises. Federal partners with large areas of undeveloped tortoise habitat may consider additional protections for that habitat through land use planning processes, potentially including time-

Fig. 6. (A) Development levels on habitat for both species of desert tortoise (shown in shades of brown) inside (green overlay) and outside of Gap Analysis Project (GAP) status 1 and 2 protected areas. (B,C) Frequency distribution of development levels for (B) Mojave and (C) Sonoran desert tortoise habitat that is on federal lands inside versus outside of GAP status 1 and 2 protected areas 


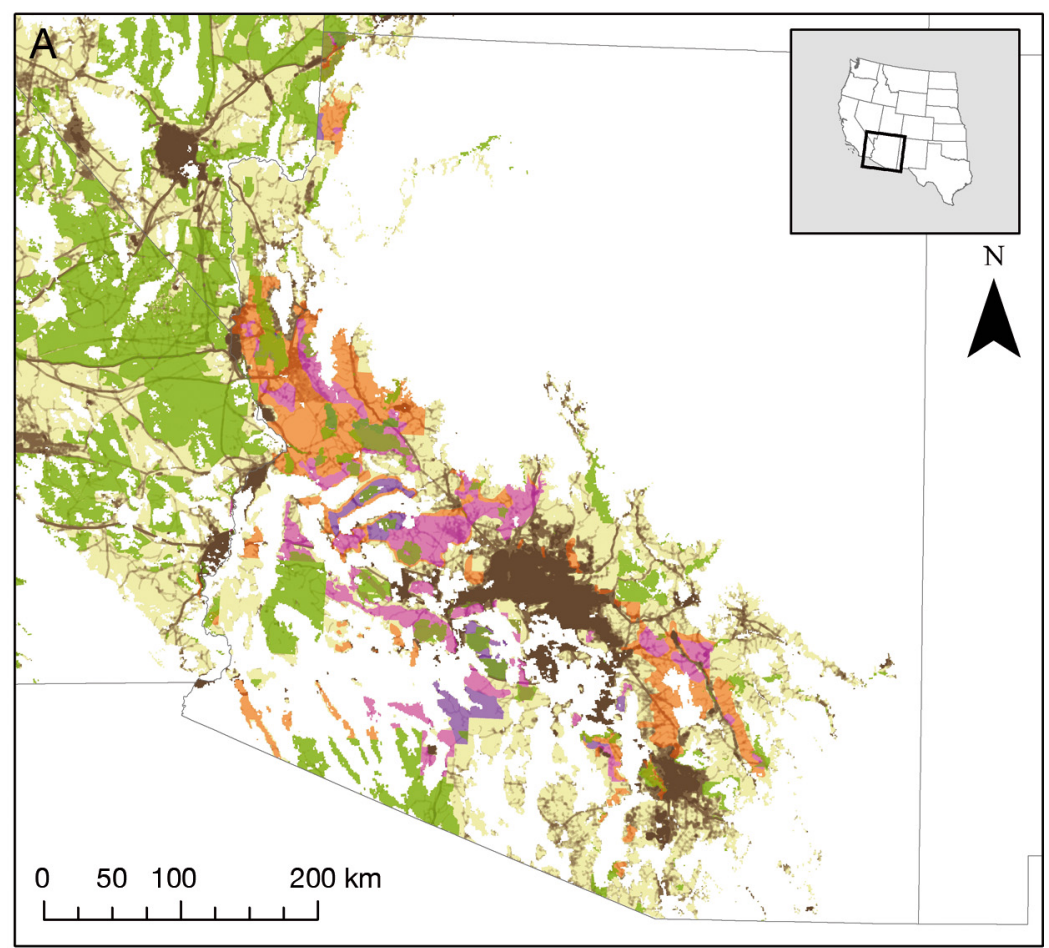

Terrestrial development index

Percent development within $1 \mathrm{~km}$ radius

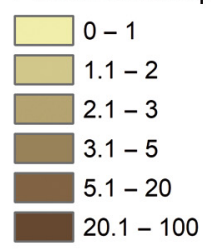

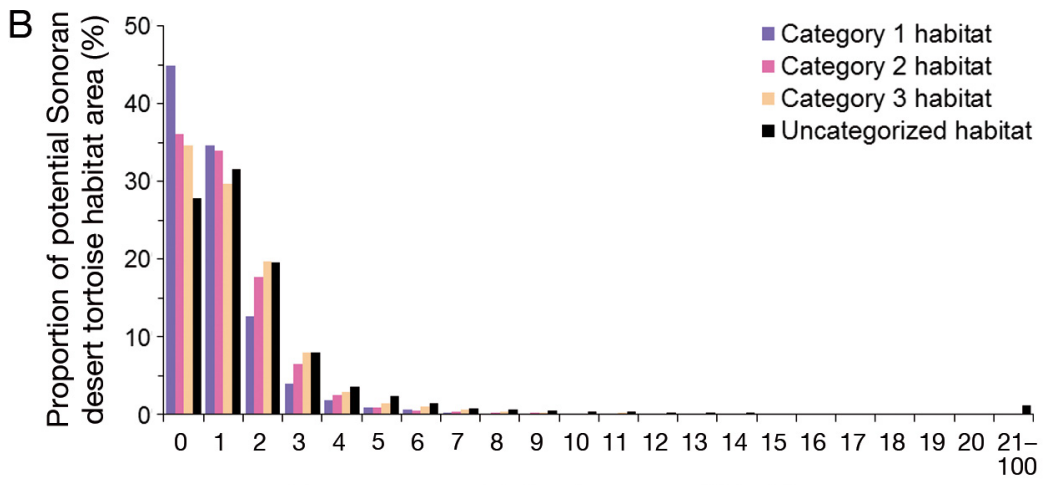

Percent terrestrial development within $1 \mathrm{~km}$

Fig. 7. (A) Development levels on desert tortoise habitat (shown in shades of brown) inside and outside of areas managed by the Bureau of Land Management in Arizona as Category 1, 2, and 3 desert tortoise habitat (purple, pink, and orange overlays, respectively) and Gap Analysis Project (GAP) status 1 and 2 protected areas (green overlays). (B) Frequency distribution of development levels for Sonoran Desert tortoise habitat managed by the Bureau of Land Management in Arizona that is designated Category 1, 2, or 3 desert tortoise habitat versus uncategorized habitat. The management goals for habitat in Categories 1-3 are described in Section 2.5.2 (Spang et al. 1988) of-year restrictions for off-trail recreational events that can minimize conflicts between tortoises and recreators during the tortoise active season.

\subsection{Evaluating threat levels on desert tortoise habitat protected by actions at national, state, and local levels}

Evaluating the effectiveness of management actions is critical for ensuring that public funds are spent wisely and for complying with required actions to protect rare species (Chape et al. 2005, Geldmann et al. 2013). Our results are a snapshot in time and do not allow formal evaluation of whether the protective action is responsible for the lower development levels inside versus outside of protected areas. However, they do demonstrate that development levels are currently lower inside compared to outside of protective designations at national levels across the range of both species, and at state and local levels in Arizona, and provide a needed baseline for evaluating the effectiveness of protective land use designations rangewide in limiting future development. The BLM is required to periodically evaluate the effectiveness of its land use plans in reaching plan goals (BLM 2005). Regular effectiveness evaluations at this local level across the range of both species could provide valuable insight into the extent to which agency actions at local levels that are intended to maintain and restore habitat for special status species (Fundamentals of Rangeland Health, 43 CFR §4180.1) are succeeding.

Land protection has been found to be effective globally in reducing conversion of natural land cover (Joppa \& Pfaff 2011), and different levels of protection correspond with different levels of change in human pressure within protected areas (Geldmann et al. 2013, Eichenwald et al. 2020). Our results were consistent with this finding: GAP status 1 and 2 protected areas, which 


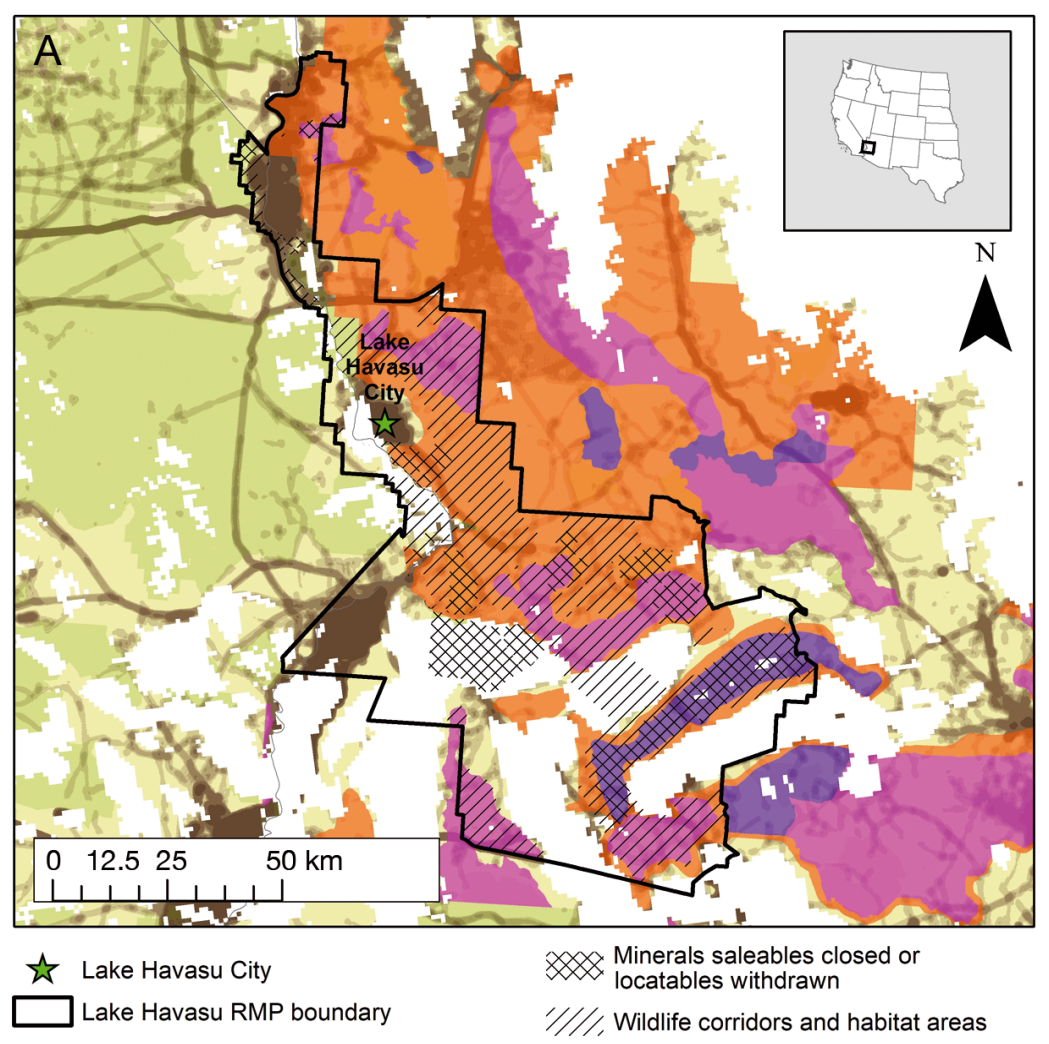

Terrestrial development index Percent development within $1 \mathrm{~km}$ radius

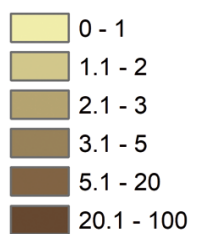

Protected desert tortoise habitat $\square$ GAP status 1 and 2 protected areas

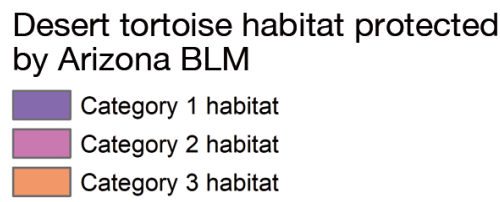

B

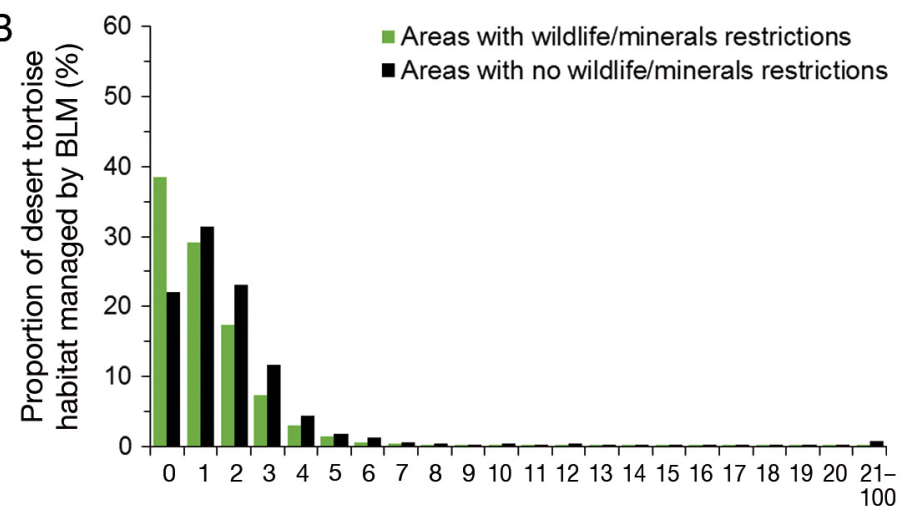

Percent terrestrial development within $1 \mathrm{~km}$

Fig. 8. (A) Protective designations (hatched areas and colored overlays) and development levels on desert tortoise habitat (shown in shades of brown) in and around the Bureau of Land Management Lake Havasu Field Office and Resource Management Plan (RMP) boundary (thick black line). GAP: Gap Analysis Project. (B) Frequency distribution of development levels for desert tortoise habitat managed by the BLM Lake Havasu Field Office that has wildlife and/or minerals restrictions in place versus habitat that is outside of both of these protection categories are permanently protected by direct action at the national level, had a larger proportion of desert tortoise habitat with no development compared to areas of habitat protected by actions at state or local levels.

We also found that multiple layers of protection were often provided to desert tortoise habitat through direct national efforts (e.g. congressional designations) as well as state- and locallevel efforts. For example, 35\% of Sonoran desert tortoise habitat in GAP status 1 or 2 protected areas is also designated as Category 1, 2, or 3 desert tortoise habitat. Further, $94 \%$ of desert tortoise habitat protected by wildlife or minerals management restrictions in the Lake Havasu Field Office is also protected as a GAP status 1 or 2 protected area, as Category 1, 2, or 3 desert tortoise habitat, or both. Such findings confirm that coordination at national, state, and local levels is strong and can provide multiple protective mechanisms for desert tortoise in high-priority locations. Protected area designations that were originally intended as permanent are being lost globally (Mascia \& Pailler 2011, Mascia et al. 2014) and in the USA (Golden Kroner et al. 2016), and some protective designations are explicitly temporary (e.g. Stamper et al. 2013). BLM resource management plans are revised approximately every 10 to $20 \mathrm{yr}$, at which point their protections are subject to change. However, local plans can be important drivers for achieving on-the-ground conservation gains (Carter et al. 2014). As a result, providing multiple layers of protection for key habitats may be an important insurance policy for long-term habitat protection for desert tortoises.

\subsection{Identifying desert tortoise} habitat with low development levels that is outside of existing protections

Using a landscape-level index of development, we were able to identify 


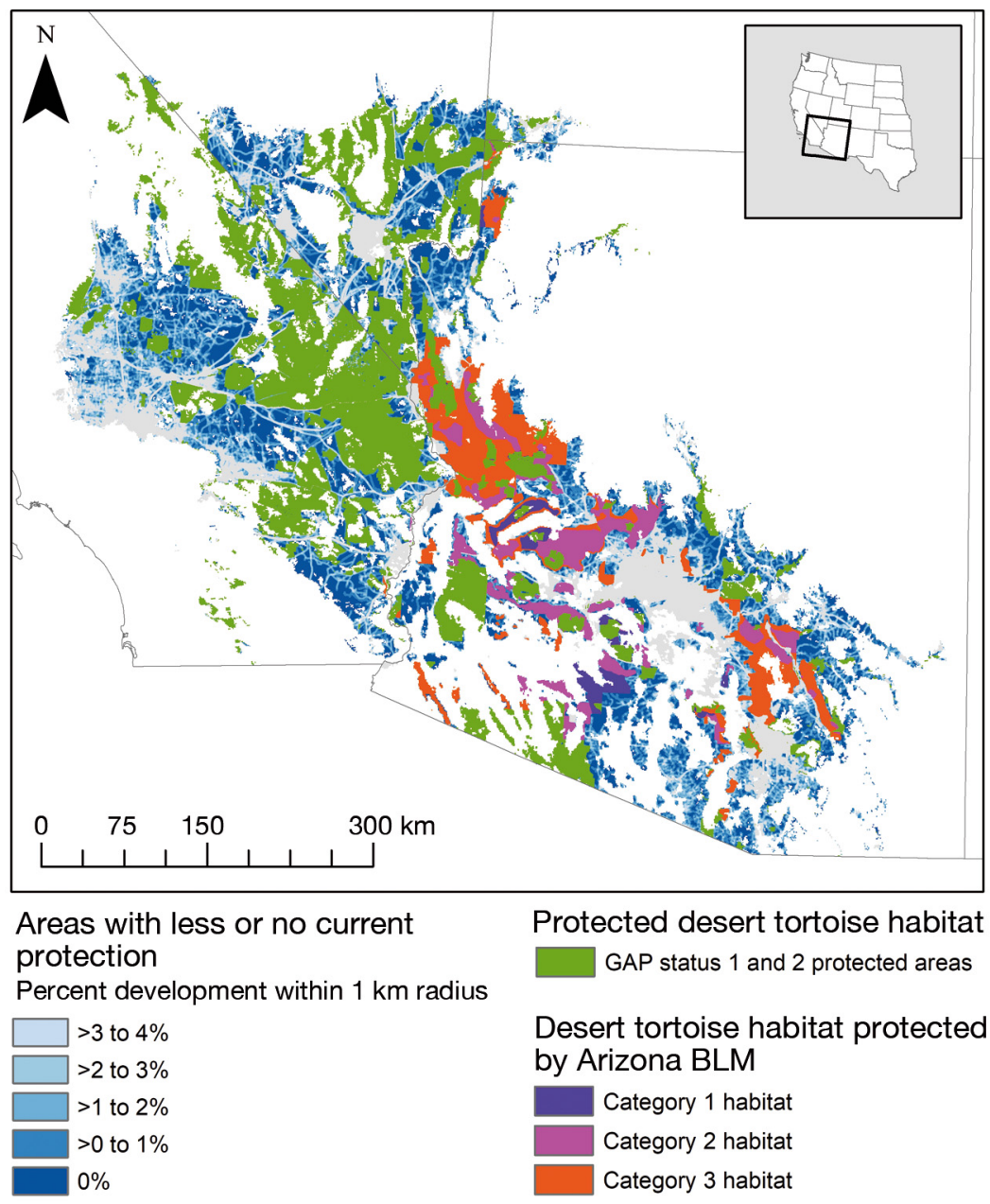

Fig. 9. Areas of desert tortoise habitat that have low development levels (shades of blue) and are outside of both Gap Analysis Project (GAP) status 1 and 2 protected areas (green) and designated desert tortoise habitat on lands managed by the Bureau of Land Management (BLM) in Arizona (purple, pink, and orange). Desert tortoise habitat that currently has low development and occurs outside both Gap Analysis Project (GAP) status 1 and 2 protected areas and designated desert tortoise habitat on lands managed by the Bureau of Land Management (BLM) in Arizona

areas of desert tortoise habitat both within and outside of BLM lands that have little or no development and in many cases are part of large contiguous patches of habitat. Development will continue to occur on many BLM lands as part of its multiple-use mission. Identifying areas on BLM lands that may warrant new protection (e.g. through land use plan restrictions) can help maintain adequate habitat for long-term persistence of healthy desert tortoise populations. Identifying relatively undeveloped habitat areas outside of BLM lands can also address habitat loss by providing opportunities for land acquisition or protection as part of mitigation for ongoing energy development on BLM lands.

\subsection{Limitations and further considerations}

Landscape-level analysis of development to inform species habitat management requires understanding levels of development that are biologically meaningful to the species. This information may be available from the literature, but often is not. Species-level monitoring often focuses on relatively pristine areas, with the result that areas with greater levels of development are less likely to be surveyed. We evaluated biologically meaningful levels of a development index using observations of live and dead Mojave desert tortoises across a range of development densities. Understanding how levels of development relate to Sonoran desert tortoises and to other response variables (e.g. disease rates, reproductive rates, genetic variability) would provide additional information on levels of development that may be compatible with persistence of desert tortoise populations in the American southwest.

We also considered a single spatial scale of analysis - a $1 \mathrm{~km}$ radius moving window - which was supported both by our analyses of Mojave desert tortoise observations and by desert tortoise ecology. However, it would be preferable to separately test the analysis scale for Sonoran desert tortoises when long-term monitoring data become available, and it may be appropriate to consider larger and/or multiple spatial scales of analysis given that different response variables (e.g. density, reproductive rates, genetic diversity) may relate to environmental changes at multiple spatial scales (Jackson \& Fahrig 2012). Populationand species-level response variables may respond at the largest spatial scales (Jackson \& Fahrig 2014), suggesting that broader analysis scales may inform actions focused at the population or species level.

The development index relies on national datasets for consistency across the western US and considers all types of development. However, different types of development tend to occur in different spatial patterns, and their effects on desert tortoises may be 
addressed by different management actions. For example, agriculture tends to be aggregated in blocks, while roads and transmission lines have long narrow linear footprints that are often more evenly and widely distributed across landscapes. As a result, the influence of roads and transmission lines is likely to far exceed their surface footprint (Kuvlesky et al. 2007), and these as well as railroads have the potential to impact long-term connectivity and genetics (Rautsaw et al. 2018, Dutcher et al. 2020). These linear features are clearly visible in our analyses (Fig. 3A). Accordingly, it may be valuable in future efforts to calculate separate indices for individual types of development (e.g. agriculture, transportation, energy) to inform specific management actions.

Roads, in particular, are ubiquitous on many multiple-use federal lands in the USA. Many roads provide critical national and international infrastructure for commerce and access to energy infrastructure, timber harvest areas, military maneuvers, and recreational visitors. In the Mojave Desert, however, the majority of 'roads' are little more than unpaved social trails established illegally and haphazardly (e.g. offhighway vehicular social trails) but with substantial negative influence on the landscape (Ouren et al. 2007 ) that is extremely difficult to ameliorate (Webb et al. 2013). Actions to increase driver awareness on roads in desert tortoise habitat do not appear to reduce road mortality (Hughson \& Darby 2013). Limiting access to roads may be more effective at reducing tortoise road mortality, and can be achieved through existing agency processes, such as BLM travel management planning, which periodically evaluate and propose changes to road presence and activity levels within individual BLM field offices. Indeed, these efforts appear to positively influence road use in some areas (Custer et al. 2017). Because many smaller unpaved roads on public lands are not mapped in national datasets (O'Donnell et al. 2014), recalculating a 'transportation' development index based on nationally available roads data augmented with locally available data for smaller roads and offroad vehicle trails may be helpful for local applications such as BLM travel management planning.

Acknowledgements. We thank Arizona Game and Fish Department for sharing new desert tortoise observation data used to map habitat for the Sonoran desert tortoise. Desert tortoise observation data have limited availability owing to sensitivity restrictions; please contact US Fish and Wildlife and individual states for more information. We thank Roy Averill-Murray for providing valuable comments on early drafts of the manuscript, and Benjamin Harms for assistance with developing the figures. The findings and conclusions provided in this article are those of the authors and do not necessarily represent the views of the University of Nevada, Bureau of Land Management, Arizona State University, or US Fish and Wildlife Service. This work was supported in part by the BLM's National Operations Center and Arizona State Office through interagency agreement L16PG00147. The BLM's Caliente District Office, Nevada, provided support in modeling both species of desert tortoise. Primary salary support for US Geological Survey authors was provided by the US Geological Survey Wildlife and Energy mission areas. The long-term monitoring program for Mojave desert tortoises has been provided through the National Training Center, Fort Irwin; the Marine Corps Air Station, Yuma; US Navy, Southwest Division; Edwards Air Force Base; the Marine Corps Air Ground Combat Center, Twentynine Palms; the Marine Corps Logistic Base; Joshua Tree National Park; Mojave National Preserve; Parashant National Park; the Clark County, Nevada, Desert Conservation Program; the BLM California Desert District; Arizona State BLM; the US Fish and Wildlife Service; and the State of Utah.

\section{LITERATURE CITED}

Allison LJ, McLuckie AM (2018) Population trends in Mojave desert tortoises (Gopherus agassizii). Herpetol Conserv Biol 13:433-452

Allred BW, Smith WK, Twidwell D, Haggerty JH, Running SW, Naugle DE, Fuhlendorf SD (2015) Ecosystem services lost to oil and gas in North America. Science 348: 401-402

Arizona Game and Fish Department (2012) Arizona's State Wildlife Action Plan: 2012-2022. Arizona Game and Fish Department, Phoenix, AZ

Averill-Murray RC, Darst CR, Field KJ, Anderson LJ (2012) A new approach to the conservation of the Mojave desert tortoise. Bioscience 62:893-899

Averill-Murray RC, Darst CR, Strout N, Wong M (2013) Conserving population linkages for the Mojave desert tortoise (Gopherus agassizii). Herpetol Conserv Biol 8:1-15

Aycrigg JL, Belote RT, Dietz MS, Aplet GH, Fischer RA (2015) Bombing for biodiversity in the United States: response to Zentils \& Lindemayer 2015. Conserv Lett 8: 306-307

*Barber JR, Burdett CL, Reed SE, Warner KA and others (2011) Anthropogenic noise exposure in protected natural areas: estimating the scale of ecological consequences. Landsc Ecol 26:1281

Barbour MG, Keeler-Wolf T, Schoenherr AA (2007) Terrestrial vegetation of California, $3^{\text {rd }}$ edn. University of California Press, Berkeley, CA

Berish JED, Medica PA (2014) Home range and movements of North American tortoises. In: Rostal DC, McCoy ED, Mushinsky HR (eds) Biology and conservation of North American tortoises. Johns Hopkins Press, Baltimore, MD, p 96-101

Berry KH, Murphy RW (2019) Gopherus agassizii (Cooper 1861) - Mojave desert tortoise, Agassiz's desert tortoise. In: Rhodin AGJ, Iverson JB, van Dijk PP, Stanford CB and others (eds) Conservation biology of freshwater turtles and tortoises: a compilation project of the IUCN/SSC Tortoise and Freshwater Turtle Specialist Group. Chelonian Res Monogr 5:109.1-109.45

BLM (Bureau of Land Management) (2005) H-1601-1 Land use planning handbook. Bureau of Land Management. 
https://www.ntc.blm.gov/krc/uploads/360/4_BLM\%20 Planning \%20Handbook\%20H-1601-1.pdf (accessed 17 April 2020)

BLM (2007) Record of decision and Lake Havasu Field Office approved resource management plan. Bureau of Land Management, Lake Havasu City, AZ

BLM (2008) Manual Section 6840 - Special Status Species Management. https://www.blm.gov/sites/blm.gov/files/ uploads/mediacenter_blmpolicymanual6840.pdf (accessed 17 Sept 2019)

Boarman WI, Sazaki M (2006) A highway's road-effect zone for desert tortoises (Gopherus agassizii). J Arid Environ 65:94-101

Boarman WI, Patten MA, Camp RJ, Collis SJ (2006) Ecology of a population of subsidized predators: common ravens in the central Mojave Desert, California. J Arid Environ $67: 248-261$

Carr NB, Leinwand IIF, Wood DJA (2016) A multiscale index of landscape intactness for the Western United States. US Geological Survey Data Release. https://www. sciencebase.gov/catalog/item/57d8779de4b090824ff9 acfb(accessed 16 April 2020)

Carr NB, Leinwand IF, Wood DJA (2017) A multiscale index of landscape intactness for management of public lands. In: Carter SK, Carr NB, Miller KH, Wood DJA (eds) Multiscale guidance and tools for implementing a landscape approach to resource management in the Bureau of Land Management. US Geological Survey Open-File Report 2016-1207, p 55-74

Carter SK, Keuler NS, Pidgeon AM, Radeloff VC (2014) Evaluating the influence of conservation plans on land protection actions in Wisconsin, USA. Biol Conserv 178: 37-49

Chape S, Harrison J, Spalding M, Lysenko I (2005) Measuring the extent and effectiveness of protected areas as an indicator for meeting global biodiversity targets. Philos Trans R Soc B 360:443-455

Colino-Rabanal VJ, Lizana M (2007) Herpetofauna and roads: a review. Basic Appl Herpetol 26:5-31

Comer P, Crist P, Reid M, Hak J and others (2013) Mojave Basin and Range Rapid Ecoregional Assessment report. NatureServe, Arlington, VA

Custer NA, Defalco LA, Nussear KE, Esque TC (2017) Drawing a line in the sand: effectiveness of off-highway vehicle management in California's Sonoran Desert. J Environ Manag 193:448-457

* Dale V, Archer S, Chang M, Ojima D (2005) Ecological impacts and mitigation strategies for rural land management. Ecol Appl 15:1879-1892

* Darst CR, Murphy PJ, Strout NW, Campbell SP, Field KJ, Allison L, Averill-Murray RC (2013) A strategy for prioritizing threats and recovery actions for at-risk species. Environ Manag 51:786-800

Davies KW, Sheley RL (2007) A conceptual framework for preventing the spatial dispersal of invasive plants. Weed Sci 55:178-184

Dolby, GA, Dorsey RJ, Graham MR (2019) A legacy of geoclimatic complexity and genetic divergence along the lower Colorado River: Insights from the geological record and 33 desert-adapted animals. J Biogeogr 45:2479-2505

* Drake KK, Esque TC, Nussear KE, Defalco LA, ScolesSciulla SJ, Modlin AT, Medica PA (2015) Desert tortoise use of burned habitat in the eastern Mojave desert. J Wildl Manag 79:618-629

₹ Duda JJ, Krzysik AJ, Freilich JE (1999) Effects of drought on desert tortoise movement and activity. J Wildl Manag 63: 1181-1192

Dutcher KE, Vandergast AG, Esque TC, Mitelberg A, Matocq MD, Heaton JS, Nussear KE (2020) Genes in space: what Mojave desert tortoise genetics can tell us about landscape connectivity. Conserv Genet 21:289-303

KEdwards T, Berry KH, Inman RD, Esque TC, Nussear KE, Jones CA, Culver M (2015) Testing taxon tenacity of tortoises: evidence for a geographical-selection gradient at a secondary contact zone. Ecol Evol 5:2095-2114

Eichenwald AJ, Evans MJ, Malcom JW (2020) US imperiled species are most vulnerable to habitat loss on private lands. Front Ecol Environ, doi:10.1002/fee.2177

Esque TC, Schwalbe CR, DeFalco LA, Hughes TJ, Duncan RB (2003) Effects of wildfire on small desert vertebrates, especially desert tortoises (Gopherus agassizii). Southwest Nat 48:103-110

Esque TC, Nussear KE, Drake KK, Walde AD and others (2010) Effects of subsidized predators, resource variability, and human population density on desert tortoise populations in the Mojave Desert, USA. Endang Species Res 12:167-177

Franklin J (2010) Mapping species distributions: spatial inference and prediction. Cambridge University Press, Cambridge

Freeman OE, Duguma LA, Minang PA (2015) Operationalizing the integrated landscape approach in practice. Ecol Soc 20:24

Freilich JE, Burnham KP, Collins CM, Garry CA (2000) Factors affecting population assessments of desert tortoises. Conserv Biol 14:1479-1489

* Gavier-Pizarro GI, Radeloff VC, Stewart SI, Huebner C, Keuler NS (2010) Rural housing is related to plant invasions into forests of southern Wisconsin, USA. Landsc Ecol 25:1505-1518

Keldmann J, Barnes M, Coad L, Craigie ID, Hockings M, Burgess ND (2013) Effectiveness of terrestrial protected areas in reducing habitat loss and population declines. Biol Conserv 161:230-238

Gergely KJ, Boykin KG, McKerrow AJ, Rubino MJ, Tarr NM, Williams SG (2019) Gap Analysis Project (GAP) terrestrial vertebrate species richness maps for the conterminous U.S. US Geological Survey Scientific Investigations Report 2019-5034

*Golden Kroner RE, Krithivasan R, Mascia MB (2016) Effects of protected area downsizing on habitat fragmentation in Yosemite National Park (USA), 1864-2014. Ecol Soc 21: 22

*Hansen AJ, Knight RL, Marzluff JM, Powell S, Brown K, Gude PH, Jones K (2005) Effects of exurban development on biodiversity: patterns, mechanisms, and research needs. Ecol Appl 15:1893-1905

Howland J, Rorabaugh J (2002) Conservation and protection of the desert tortoise in Arizona. In: Van Devender TR (ed) The Sonoran desert tortoise: natural history, biology, and conservation. Arizona-Sonora Desert Museum and The University of Arizona Press, Tucson, AZ, p 334-354

Hughson DL, Darby N (2013) Desert tortoise road mortality in Mojave National Preserve, California. Calif Fish Game 99:222-232

Ibisch PL, Hoffmann MT, Kreft S, Pe'er G and others (2016) A global map of roadless areas and their conservation status. Science 354:1423-1427

Inman RD, Nussear KE, Esque TC, Vandergast AG and others (2014) Mapping habitat for multiple species in 
the Desert Southwest. US Geol Surv Open-File Rep 2014-1134

Inman RD, Fotheringham AS, Franklinn J, Esque TC, Edwards T, Nussear KE (2019) Local niche differences predict genotype associations in sister taxa of desert tortoise. Divers Distrib 25:1194-1209

Jackson HB, Fahrig L (2012) What size is a biologically relevant landscape? Landsc Ecol 27:929-941

Jackson ND, Fahrig L (2014) Landscape context affects genetic diversity at a much larger spatial extent than population abundance. Ecology 95:871-881

Jones NF, Pejchar L, Kiesecker JM (2015) The energy footprint: how oil, natural gas, and wind energy affect land for biodiversity and the flow of ecosystem services. Bioscience 65:290-301

Joppa LN, Pfaff A (2011) Global protected area impacts. Proc R Soc B 278:1633-1638

Keeler-Wolf T (2007) Mojave Desert scrub vegetation. In: Barbour MG, Keeler-Wolf T, Schoenherr AA (eds) Terrestrial vegetation of California, 3rd edn. University of California Press, Berkeley, CA, p 609-656

Kight CR, Swaddle JP (2011) How and why environmental noise impacts animals: an integrative, mechanistic review. Ecol Lett 14:1052-1061

Kuvlesky WP, Brennan LA, Morrison ML, Boydston KK, Ballard BM, Bryant FC (2007) Wind energy development and wildlife conservation: challenges and opportunities. J Wildl Manag 71:2487-2498

Leinwand IIF, Theobald DM, Mitchell J, Knight RL (2010) Landscape dynamics at the public-private interface: a case study in Colorado. Landsc Urban Plan 97:182-193

Leu M, Hanser SE, Knick ST (2008) The human footprint in the west: a large-scale analysis of anthropogenic impacts. Ecol Appl 18:1119-1139

* Liu C, Berry PM, Dawson TP, Pearson RG (2005) Selecting thresholds of occurrence in the prediction of species distributions. Ecography 28:385-393

Lovich JE, Ennen JR (2011) Wildlife conservation and solar energy development in the Desert Southwest, United States. Bioscience 61:982-992

MacMahon JA, Wagner FH (1985) The Mojave, Sonoran and Chihuahuan deserts of North America. In: Evenari M, Noy-Meir I, Goodall DW (eds) Ecosystems of the world, Vol 12A. Elsevier Press, Amsterdam, p 105-202

* Mascia MB, Pailler S (2011) Protected area downgrading, downsizing, and degazettement (PADDD) and its conservation implications. Conserv Lett 4:9-20

Mascia MB, Pailler S, Krithivasan R, Roshchanka V and others (2014) Protected area downgrading, downsizing, and degazettement (PADDD) in Africa, Asia, and Latin America and the Caribbean, 1900-2010. Biol Conserv 169: 355-361

McKinney ML (2002) Urbanization, biodiversity, and conservation. Bioscience 52:883-890

McLuckie AM, Lamb T, Schwalbe CR, McCord RD (1999) Genetic and morphometric assessment of an unusual tortoise (Gopherus agassizii) population in the Black Mountains of Arizona. J Herpetol 33:36-44

Murphy RW, Berry KH, Edwards T, Leviton AE, Lathrop A, Riedle JD (2011) The dazed and confused identity of Agassiz's land tortoise, Gopherus agassizii (Testudines: Testudinidae) with the description of a new species and its consequences for conservation. ZooKeys 113:39-71

Nowicki SA, Inman RD, Esque TC, Nussear KE, Edwards CS (2019) Spatially consistent high-resolution land surface temperature mosaics for thermophysical mapping of the Mojave Desert. Sensors (Basel) 19:2669

Nussear KE, Tuberville T (2014) Habitat characteristics of North American tortoises. In: Rostal D, McCoy ED, Mushinsky H (eds) Biology and conservation of North American tortoises. Johns Hopkins Press, Baltimore, MD, p 77-84

Nussear KE, Esque TC, Inman RD, Gass L and others (2009) Modeling habitat of the desert tortoise (Gopherus agassizii) in the Mojave and parts of the Sonoran Deserts of California, Nevada, Utah, and Arizona. US Geol Surv Open-File Rep (US) 2009-1102

O'Donnell MS, Fancher TS, Freeman AT, Ziegler AE, Bowen $\mathrm{ZH}$, Aldridge CL (2014) Large scale Wyoming transportation data - a resource planning tool. US Geol Surv Data Ser 821, doi:10.3133/ds821

Ouren DS, Haas C, Melcher CP, Stewart SC and others (2007) Environmental effects of off-highway vehicles on Bureau of Land Management lands: a literature synthesis, annotated bibliographies, extensive bibliographies, and internet resources. US Geol Surv Open-File Rep 2007-1353

*Parker SS, Cohen BS, Moore J (2018) Impact of solar and wind development on conservation values in the Mojave Desert. PLOS ONE 13:e0207678

R Core Team (2016) R: a language and environment for statistical computing. R Foundation for Statistical Computing, Vienna

Rautsaw RM, Martin SA, Vincent BA, Lanctot K, Bolt MR, Seigel RA, Parkinson CL (2018) Stopped dead in their tracks: the impact of railways on gopher tortoise (Gopherus polyphemus) movement and behavior. Copeia 106:135-143

* Sayer J, Sunderland T, Ghazoul J, Pfund JL and others (2013) Ten principles for a landscape approach to reconciling agriculture, conservation, and other competing land uses. Proc Natl Acad Sci USA 110:8349-8356

Spang EF, Lamb GW, Rowley F, Radtkey WH, Olendorff RR, Dahlem EA, Stine S (1988) Desert tortoise habitat management on the public lands: a rangewide plan. Bureau of Land Management, Division of Wildlife and Fisheries, Washington, DC

Stamper TJ, Hicke JA, Jennings M, Aycrigg J (2013) Spatial and temporal patterns of changes in protected areas across the Southwestern United States. Biodivers Conserv 22:343-356

F Stein BA, Scott C, Benton N (2008) Federal lands and endangered species: the role of military and other federal lands in sustaining biodiversity. Bioscience 58:339-347

Strittholt JR, Bryce SA, Ward BC, Bachelet DM (2012) Sonoran Desert Rapid Ecoregional Assessment report. Prepared for the Bureau of Land Management, Denver, CO. https://landscape.blm.gov/REA_General_Docs/SOD_ Final_Report_Body.pdf (accessed 16 April 2020)

* Tracy CR, Averill-Murray RC, Boarman WI, Delehanty DJ and others (2004) Desert Tortoise Recovery Plan Assessment. US Fish and Wildlife Service, Reno, NV

Turner RM (1994) Mohave desertscrub. In: Brown DE (ed) Biotic communities of the American Southwest - United States and Mexico. University of Utah Press, Salt Lake City, UT, p 157-168

Turner RM, Brown DE (1994) Sonoran desertscrub. In: Brown DE (ed) Biotic communities of the American Southwest-United States and Mexico. University of Utah Press, Salt Lake City, UT, p 181-221 
US Department of the Interior (2017) Our priorities: American energy, climate change, jobs, regulatory reform, stewardship, and tribal nations. https://www.doi.gov/ ourpriorities (accessed 19 Oct 2017)

US Environmental Protection Agency (1996) Level III and IV ecoregions of the continental United States. US Environmental Protection Agency, Office of Information Resources Management. https://www.epa.gov/eco-research/ level-iii-and-iv-ecoregions-continental-united-states (accessed 14 Aug 2017)

US Fish and Wildlife Service (1990) Endangered and threatened wildlife and plants; determination of threatened status for the Mojave population of the desert tortoise. Fed Regist 55:12178-12191

US Fish and Wildlife Service (2011) Revised recovery plan for the Mojave population of the desert tortoise (Gopherus agassizii). US Fish and Wildlife Service, Sacramento, CA

US Fish and Wildlife Service (2015a) Range-wide monitoring of the Mojave desert tortoise (Gopherus agassizii): 2013 and 2014 Annual Reports. Desert Tortoise Recovery

Editorial responsibility: Abi Tamim Vanak,

Bangalore, India
Office, US Fish and Wildlife Service, Reno, NV

US Fish and Wildlife Service (2015b) Species Status Assessment for the Sonoran desert tortoise. Version 1.0, September 2015. US Fish and Wildlife Service, Albuquerque, NM

US Fish and Wildlife Service (2016) Range-wide monitoring of the Mojave desert tortoise (Gopherus agassizii): 2015 and 2016 Annual Reporting. Desert Tortoise Recovery Office, US. Fish and Wildlife Service, Reno, NV

*US Geological Survey (2016) Gap Analysis Program (GAP) Protected Areas Database of the United States (PAD-US), version 1.4, Combined feature class. Released May 2016. https://gapanalysis.usgs.gov/padus/data/download/ (accessed 25 Apr 2017)

von Seckendorff Hoff K, Marlow RW (2002) Impacts of vehicle road traffic on desert tortoise populations with consideration of conservation of tortoise habitat in southern Nevada. Chelonian Conserv Biol 4:449-456

Webb RH, Esque TC, Nussear KE, Sturm M (2013) Disruption rates for one vulnerable soil in Organ Pipe Cactus National Monument, Arizona. J Arid Environ 95:75-83

Submitted: October 24, 2019; Accepted: June 5, 2020 Proofs received from author(s): July 24, 2020 